\title{
Bathymetric distribution of brachyuran crab (Crustacea, Decapoda) communities on coastal soft bottoms off southeastern Brazil
}

\author{
Giovana Bertini $^{1, *}$, Adilson Fransozo ${ }^{2}$ \\ ${ }^{1}$ NEBECC (Group of Studies of Crustacean Biology, Ecology and Culture), Universidade Estadual Paulista, Unidade \\ Diferenciada de Registro, Rua Tamekichi Takano 5, Centro, 11900-000, Registro, SP, Brazil \\ ${ }^{2}$ NEBECC (Group of Studies of Crustacean Biology, Ecology and Culture), Departamento de Zoologia, Instituto de \\ Biociências, Universidade Estadual Paulista, UNESP, s/n, 18618-000, Botucatu, SP, Brazil
}

\begin{abstract}
The communities of brachyuran crabs living on soft bottoms off Ubatuba in SE Brazil were studied with respect to their structure, bathymetric distribution, composition, diversity and indices of similarity. The data were analyzed using multivariate techniques of classification and ordination. Most of the individuals caught during summer were the swimming crab Portunus spinicarpus at the $35 \mathrm{~m}$ isobath, which contributed to the much-decreased diversity in this season and site. Multivariate analysis indicated that the species were distributed according to depth and also in relation to environmental gradients.
\end{abstract}

KEY WORDS: Sublittoral communities · Distribution patterns · Species composition · Crustacea · Brachyura Resale or republication not permitted without written consent of the publisher

\section{INTRODUCTION}

According to Hecker (1990) and Schaff et al. (1992), the zonation of fauna living in soft bottom marine habitats is probably related to a complex group of physical and biological factors, with the relative importance of each factor varying among different areas. Aschan (1990), Hyland et al. (1991), Blake \& Grassle (1994), Borg \& Schembri (1999) and Soto et al. (1999) all suggested that variations in the composition of benthic communities are associated with the depth gradient. Diversity in benthic marine communities may be linked to many factors such as productivity, trophic relationships and biological interactions, which vary in importance according to depth (Rex 1981).

Although the number of researchers dealing with the ecology of decapod crustaceans has increased in recent years, information on the bathymetric distribution of their communities is still scarce. In the region off Ubatuba in southeastern Brazil, only Pires (1992) and Sumida \& Pires-Vanin (1997) have studied the distribution of benthic organisms as a whole, in association with environmental factors and depth gradients, to determine community structures. The present work analyzed the community structure of brachyuran crabs from the soft bottom sublittoral zone off Ubatuba, focusing on community composition in relation to depth, and diversity patterns. The influence of environmental factors on the species distribution patterns was also investigated.

\section{MATERIALS AND METHODS}

Data collection. Crabs were collected monthly from January through December 2000 from a shrimp boat equipped with 2 otter-trawl nets (double-rig) with the following net specifications: length $11 \mathrm{~m}$, mouth $4.5 \mathrm{~m}$, body mesh diameter $25 \mathrm{~mm}$, cod-end mesh diameter $15 \mathrm{~mm}$. Each of 9 transects ( $2 \mathrm{~km}$ each) was trawled for a 30 min period, sampling a total area of about $18000 \mathrm{~m}^{2}$. Four transects, which included the bays of Ubatumirim, Ubatuba and Mar Virado, were sampled once during each season of the year at the $2,5,10$, and 


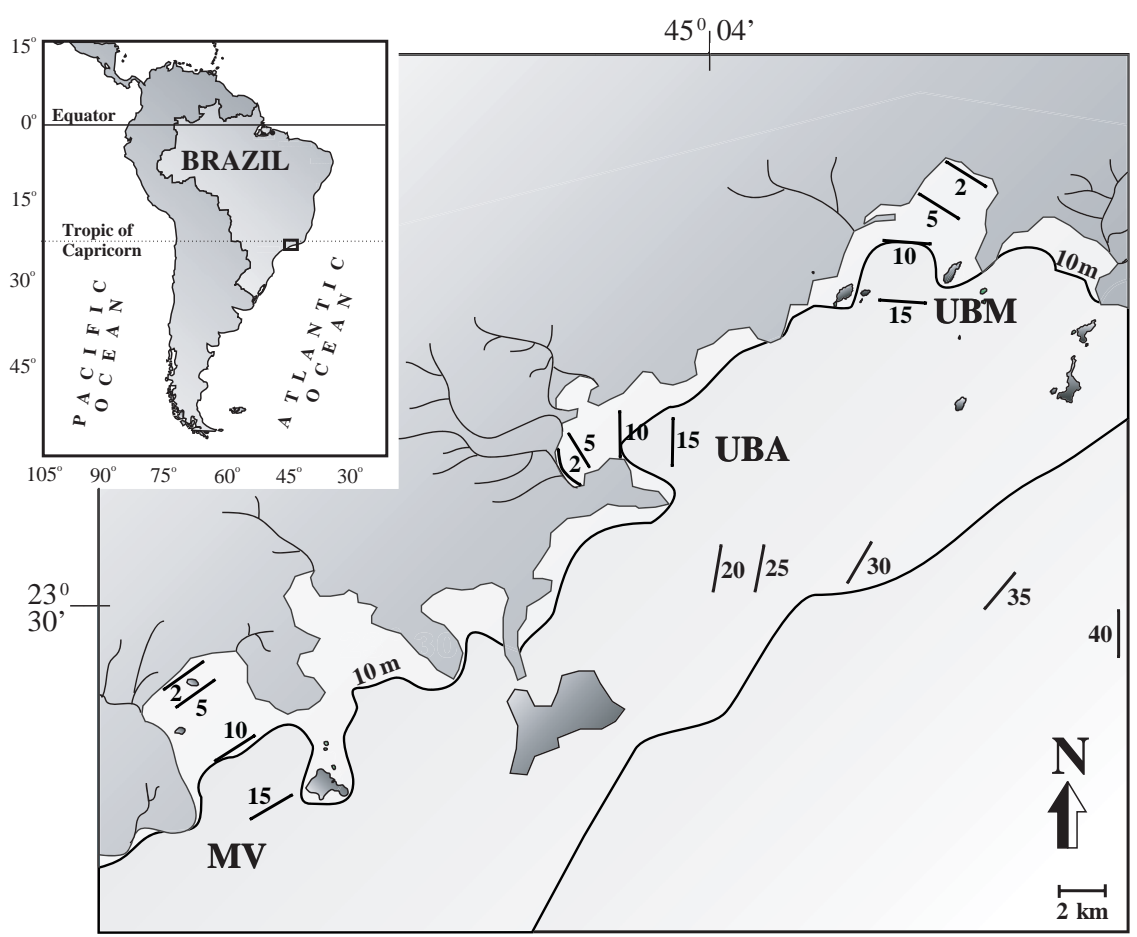

Fig. 1. The Ubatuba region, indicating the sampling depths in the bays of Ubatumirim (UBM), Ubatuba (UBA), and Mar Virado (MV) and in the outer zone (20 to $40 \mathrm{~m}$ )

$15 \mathrm{~m}$ isobaths. Extra trawls were made monthly in the middle zones of these bays along the 20,25, 30, 35 and $40 \mathrm{~m}$ isobaths (Fig. 1), here considered as an outer zone. An ecobathymeter coupled with a GPS was used to record the depths at the sampling sites.

After each trawl, the brachyuran crabs were sorted, placed in plastic bags, labeled, and stored on shaved ice. In the laboratory, specimens were counted and identified according to Melo (1996). The classification adopted for brachyurans was that of Martin \& Davis (2001).

Salinity $(\%)$ and temperature $\left({ }^{\circ} \mathrm{C}\right)$ were measured in bottom-water samples, obtained each month for each transect, by means of a Nansen bottle.

Sediment samples were collected seasonally with a $0.06 \mathrm{~m}^{2}$ Van Veen grab. In the laboratory, the sediment was oven-dried at $70^{\circ} \mathrm{C}$ for $72 \mathrm{~h}$. For analysis of grain size composition, two $50 \mathrm{~g}$ sub-samples were separated, treated with $250 \mathrm{ml}$ of a $0.2 \mathrm{~N} \mathrm{NaOH}$ solution and stirred for 5 min to release silt and clay particles. Sub-samples were then rinsed on a $0.063 \mathrm{~mm}$ sieve. Sediments were sieved through $2 \mathrm{~mm}$ (gravel); 2.0-1.0 mm (very coarse sand); $1.0-0.5 \mathrm{~mm}$ (coarse sand); $0.5-0.25 \mathrm{~mm}$ (medium sand); $0.25-0.125 \mathrm{~mm}$ (fine sand); $0.125-0.063 \mathrm{~mm}$ (very fine sand); smaller particles were classified as silt-clay. Cumulative particle size curves were computer-plotted using the phi scale and phi values corresponding to the 16th, 50th and 84th percentiles were read from the curves to determine the mean diameter of the sediment. This was calculated by the formula $\mathrm{Md}=\left(\varphi_{16}+\varphi_{50}+\varphi_{84}\right) / 3$. The value of phi was calculated by the formula $\varphi=-\log _{2} d$, where $d=$ grain diameter $(\mathrm{mm})$.

The organic matter content of the sediment was calculated by the difference between the ash-free dry weights of three $10 \mathrm{~g}$ substrate subsamples incinerated in porcelain crucibles at $500^{\circ} \mathrm{C}$ for $3 \mathrm{hr}$.

All the procedures for sediment analysis followed Hakanson \& Jansson (1983) and Tucker (1988).

Data analysis. Species diversity was calculated using the Shannon-Wiener index (Pielou 1966): $H^{\prime}=\sum_{i=1}^{s} P_{i} \cdot \log _{2} P_{\mathrm{i}}$, where $s$ is the number of species and $P_{\mathrm{i}}$ is the proportion of the $\mathrm{i}^{\text {th }}$ species. Evenness $\left(J^{\prime}\right)$ was calculated as indicated by Pielou (1975): $J^{\prime}=H^{\prime} / \log _{2} S$.

Prior to the multivariate analysis, the data were simplified by eliminating species which appeared less than 3 times in the collections, as well as individuals which could not be identified

to species level.

Cluster analysis was performed among species (mode $\mathrm{R}$ ) and among sites (mode Q), using the Canberra metric similarity coefficient, after the data were square-root transformed (Lance \& Williams 1967). The linking method utilized was unweighted-pair group averaging (UPGMA); this technique is commonly used in ecology and may be the best for translating affinity dendrograms of the original matrix (Gauch \& Whittaker 1981).

The data were ordered by canonical correlation analysis (Gittins 1985) to reveal patterns among different depths and seasons of the year.

The statistical analyses were performed with the SAS statistical package (version 6.12) (SAS Institute 1996). The diversity index and the matrices of similarity were provided by the Krebs program (version 0.9) (Krebs 1998).

\section{RESULTS}

\section{Environmental data}

The sediment from the 20 and $35 \mathrm{~m}$ depths was poorly sorted and had a smaller mean diameter (phi) (Fig. 2). Sediment organic matter content varied with depth, with the highest mean percentage $(6.2 \%)$ at $10 \mathrm{~m}$ and the lowest (2.1\%) at $30 \mathrm{~m}$ (Fig. 3). 


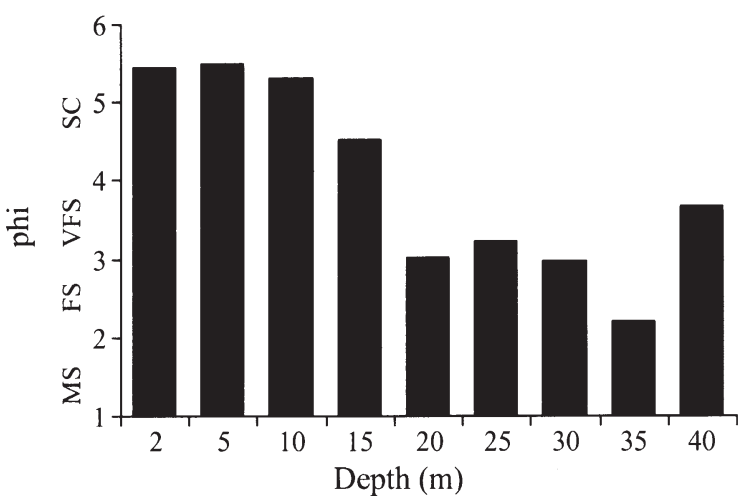

Fig. 2. Central tendency of bottom sediments represented by mean diameter (phi) for each sampled depth (MS = medium sand; FS = fine sand; VFS = very fine sand; $\mathrm{SC}=$ silt + clay)

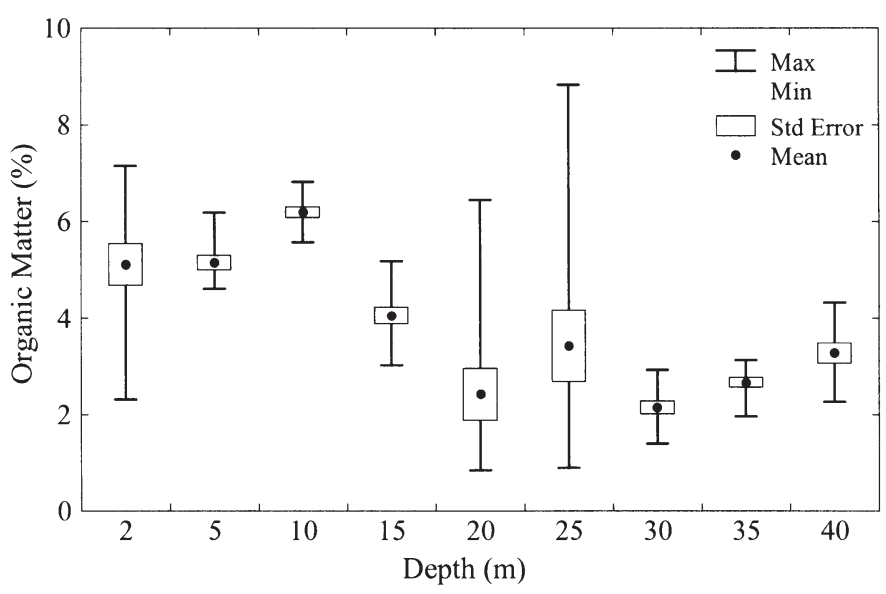

Fig. 3. Mean, maximum, and minimum content of organic matter for the sediments at each sampling depth

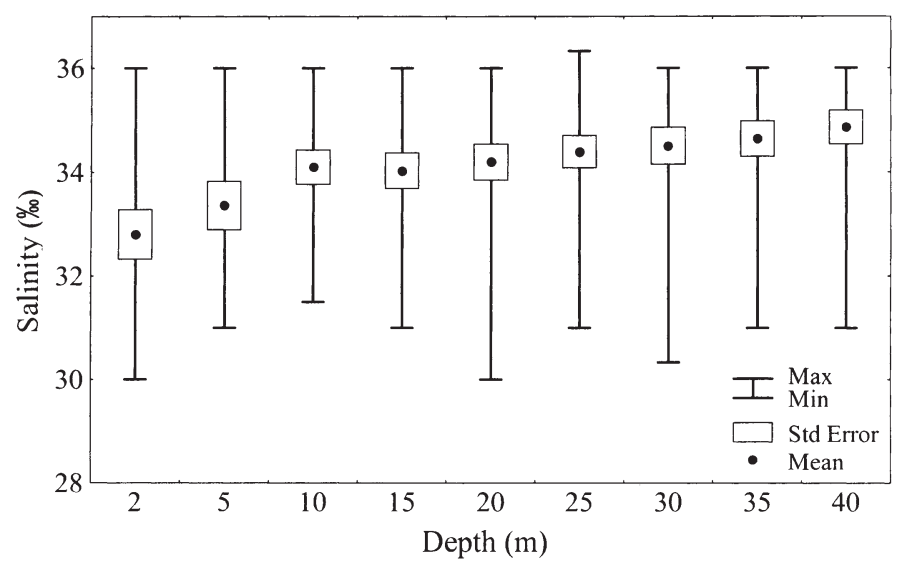

Fig. 4. Mean, maximum, and minimum salinity at each sampling depth

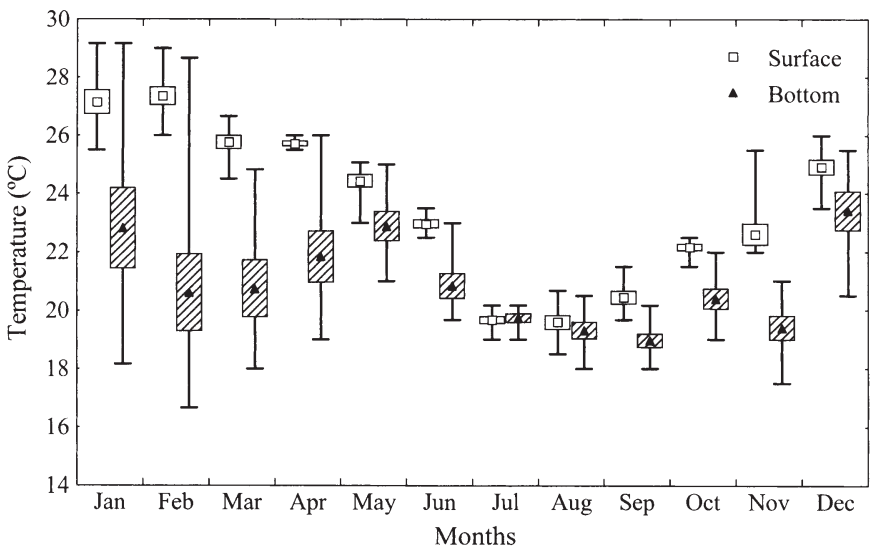

Fig. 5. Monthly means and ranges of variation of the surface and bottom water temperatures. (Box $=$ standard error)

Mean bottom salinity was lowest at $2 \mathrm{~m}(33.1 \%)$ and highest at $40 \mathrm{~m}$ (35.4\%) (Fig. 4).

Both surface and bottom temperatures (Fig. 5) underwent wide seasonal changes, with the lowest mean temperatures in winter (July through September).

\section{Community analysis}

The total catch of 9315 brachyurans included representatives of 9 superfamilies, 24 genera, and 38 species. Species records by season are represented in Table 1. The highest numbers of crabs were caught in summer, when the swimming crab Portunus spinicarpus was extremely abundant at the $35 \mathrm{~m}$ isobath.

Similar numbers of species were found at the different bottom depths. However, the species composition changed gradually with depth, mainly on bottoms deeper than $25 \mathrm{~m}$. For example, the swimming crabs Callinectes ornatus and Callinectes danae occurred mainly in the inner areas; while Leurocyclus tuberculosus, Parthenope pourtalesii, Portunus spinicarpus and Pilumnoides coelhoi were restricted to the outer areas.

Table 2 lists the spatial distributions of the individual species. Only 3, Hepatus pudibundus, Libinia spinosa and Pyromaia tuberculata, appeared at all depths. Portunus spinimanus and Callinectes ornatus were never collected at 2 and $40 \mathrm{~m}$, respectively.

The estimated diversity index was lowest at the $35 \mathrm{~m}$ isobath; a low evenness value (0.19) was obtained at this site, resulting in a lower estimated diversity $(0.72)$ than at the other sites. The highest diversity was estimated at the $25 \mathrm{~m}$ isobath (2.51) because of the greater evenness of the data (0.68) (Fig. 6a). Diversity was lowest in summer because of the huge numbers of Portunus spinicarpus present at that time, which caused a decrease in evenness (Fig. 6b). 
Table 1. Number of individuals of each crab species collected off Ubatuba from January through December 2000, by season

\begin{tabular}{|c|c|c|c|c|c|}
\hline $\begin{array}{l}\text { Superfamily/ } \\
\text { Species }\end{array}$ & Summer & Fall & $\begin{array}{l}\text { Season } \\
\text { Winter }\end{array}$ & Spring & Total \\
\hline \multicolumn{6}{|l|}{ Dromioidea } \\
\hline Cryptodromiopsis antillensis & 5 & & 3 & 3 & 11 \\
\hline \multicolumn{6}{|l|}{ Homoloidea } \\
\hline Homola barbata & & 1 & & & 1 \\
\hline \multicolumn{6}{|l|}{ Calappoidea } \\
\hline Hepatus pudibundus & 367 & 461 & 549 & 431 & 1808 \\
\hline \multicolumn{6}{|l|}{ Leucosioidea } \\
\hline Persephona lichtensteinii & 1 & & & & 1 \\
\hline Persephona mediterranea & 33 & 29 & 102 & 30 & 194 \\
\hline Persephona punctata & 9 & & 2 & 1 & 12 \\
\hline \multicolumn{6}{|l|}{ Majoidea } \\
\hline Collodes rostratus & & & 1 & & 1 \\
\hline Libinia ferreirae & & & 1 & 8 & 9 \\
\hline Libinia spinosa & 172 & 97 & 69 & 36 & 374 \\
\hline Microphrys bicornutus & 1 & 1 & 5 & 1 & 8 \\
\hline Notolopas brasiliensis & & & 1 & & 1 \\
\hline Pyromaia tuberculata & 16 & 12 & 9 & 3 & 40 \\
\hline Pelia rotunda & & & 2 & & 2 \\
\hline Leucippa pentagona & 4 & 4 & 3 & 1 & 12 \\
\hline Leurocyclus tuberculosus & 10 & 57 & 7 & 12 & 86 \\
\hline Rochinia sp. & & & 23 & & 23 \\
\hline Rochinia gracilipes & 16 & 19 & 1 & 6 & 42 \\
\hline Stenorhynchus seticornis & & & 3 & 15 & 18 \\
\hline \multicolumn{6}{|l|}{ Parthenopoidea } \\
\hline Parthenope aylthoni & 1 & & & & 1 \\
\hline Parthenope fraterculus & 1 & & 1 & & 2 \\
\hline Parthenope pourtalesii & & 3 & & 1 & 4 \\
\hline \multicolumn{6}{|l|}{ Portunoidea } \\
\hline Arenaeus cribrarius & 46 & 42 & 39 & 36 & 163 \\
\hline Callinectes sp. & & 1 & & & 1 \\
\hline Callinectes danae & 124 & 191 & 242 & 65 & 622 \\
\hline Callinectes ornatus & 931 & 219 & 1177 & 609 & 2936 \\
\hline Callinectes sapidus & & 3 & & & 3 \\
\hline Charybdis hellerii & & & 3 & & 3 \\
\hline Portunus ordwayi & 1 & & & & 1 \\
\hline Portunus spinicarpus & 1800 & 334 & 183 & 135 & 2452 \\
\hline Portunus spinimanus & 19 & 48 & 157 & 179 & 403 \\
\hline \multicolumn{6}{|l|}{ Xanthoidea } \\
\hline Hexapanopeus paulensis & 17 & 13 & 6 & 1 & 37 \\
\hline Hexapanopeus schmitti & & 3 & 3 & 2 & 8 \\
\hline Menippe nodifrons & 1 & & & & 1 \\
\hline Pilumnus reticulatus & 1 & & & & 1 \\
\hline Pilumnoides coelhoi & 6 & 5 & 4 & & 15 \\
\hline Pilumnoides hassleri & 9 & & 1 & 3 & 13 \\
\hline Pilumnoides perlatus & 1 & & & & 1 \\
\hline \multicolumn{6}{|l|}{ Pinnotheroidea } \\
\hline Pinnixa sp. & & & 2 & 3 & 5 \\
\hline Total of individuals & 3592 & 1544 & 2599 & 1581 & 9315 \\
\hline Number of species & 25 & 20 & 28 & 22 & 38 \\
\hline
\end{tabular}
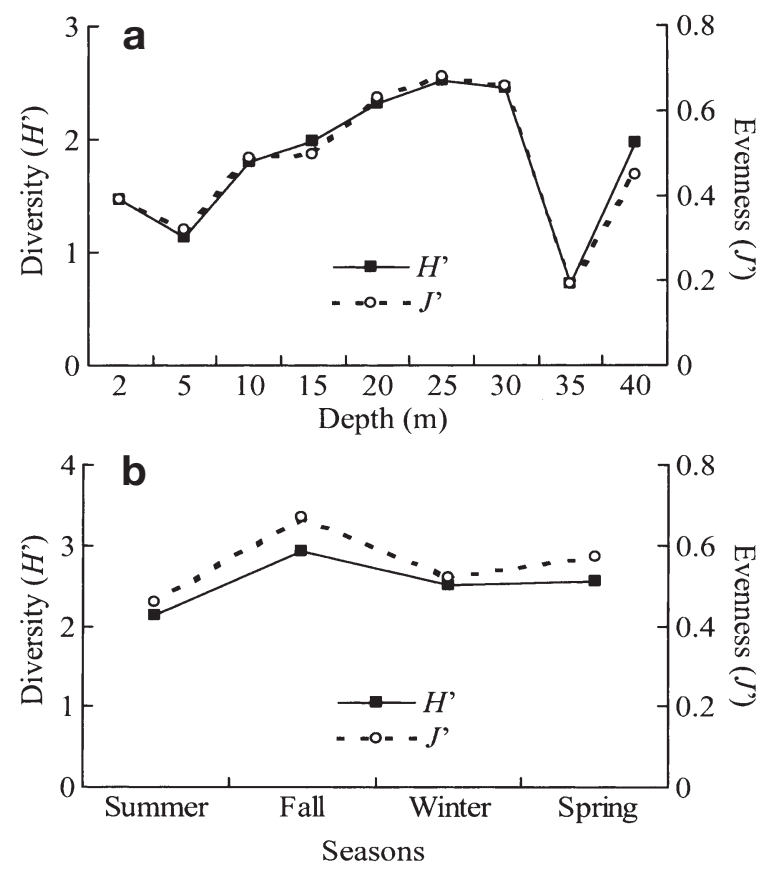

Fig. 6. (a) Spatial and (b) seasonal changes in diversity $\left(H^{\prime}\right)$ and evenness $\left(J^{\prime}\right)$ of the crab community off Ubatuba from January through December 2000

\section{Canonical analysis}

After the species caught in fewer than 3 collections were eliminated, the remaining 22 species were included in the multivariate analysis.

The canonical correlation analysis of species abundance (SP) and the environmental factors (EF) revealed 2 significant pairs $(p=$ 0.001 ) of canonical variates, which together explained $88 \%$ of the total variation of the data. The coefficients of correlation between the original variables and the canonical variates $\left(\mathrm{SP}_{1}, \mathrm{SP}_{2}, \mathrm{EF}_{1}, \mathrm{EF}_{2}\right)$ are listed in Table 3.

The canonical variate group for species of the first pair of canonical variates $\left(\mathrm{SP}_{1} \times \mathrm{EF}_{1}\right)$ was principally represented by 8 species, of which Portunus spinicarpus, Rochinia gracilipes, Leurocyclus tuberculosus, Pilumnoides coelhoi and Pilumnoides hassleri showed positive coefficients; while Arenaeus cribrarius, Callinectes ornatus and Callinectes danae showed negative coefficients. The canonical variate group for environmental factors $\left(E_{1}\right)$ was represented by a depth factor with a positive coefficient; bottom temperature and mean grain diameter (phi), both with negative coefficients. These results indicate that the 
Table 2. Number of individuals of each crab species collected off Ubatuba from January through December 2000, by sampling depth

\begin{tabular}{|c|c|c|c|c|c|c|c|c|c|c|}
\hline \multirow{2}{*}{$\begin{array}{l}\text { Superfamily/ } \\
\text { Species }\end{array}$} & \multicolumn{9}{|c|}{ Depth (m) } & \multirow[t]{2}{*}{ Total } \\
\hline & 2 & 5 & 10 & 15 & 20 & 25 & 30 & 35 & 40 & \\
\hline \multicolumn{11}{|l|}{ Dromioidea } \\
\hline C. antillensis & & & & & & & & 8 & 3 & 11 \\
\hline \multicolumn{11}{|l|}{ Homoloidea } \\
\hline H. barbata & & & & & & & & & 1 & 1 \\
\hline \multicolumn{11}{|l|}{ Calappoidea } \\
\hline H. pudibundus & 52 & 127 & 244 & 593 & 228 & 232 & 53 & 15 & 26418 & 1808 \\
\hline \multicolumn{11}{|l|}{ Leucosioidea } \\
\hline P. lichtensteinii & & & & 1 & & & & & & 1 \\
\hline P. mediterranea & & & 6 & 73 & 59 & 46 & 3 & 1 & 6 & 194 \\
\hline P. punctata & 2 & 2 & 5 & 3 & & & & & & 12 \\
\hline \multicolumn{11}{|l|}{ Majoidea } \\
\hline C. rostratus & & & & & & & 1 & & & 1 \\
\hline L. ferreirae & 1 & 6 & 1 & & & 1 & & & & 9 \\
\hline L. spinosa & 4 & 5 & 11 & 37 & 41 & 120 & 70 & 44 & 42 & 374 \\
\hline M. bicornutus & & & 1 & 2 & 4 & & 1 & & & 8 \\
\hline N. brasiliensis & & & & & 1 & & & & & 1 \\
\hline P. tuberculata & 2 & 1 & 4 & 6 & 3 & 4 & 8 & 5 & 7 & 40 \\
\hline P. rotunda & & 1 & & 1 & & & & & & 2 \\
\hline L. pentagona & & & & & 1 & 4 & 1 & 2 & 4 & 12 \\
\hline L. tuberculosus & & & & & & 8 & 17 & 39 & 22 & 86 \\
\hline Rochinia sp. & & & & & & 2 & & 19 & 2 & 23 \\
\hline R. gracilipes & & & & & & & 1 & & 41 & 42 \\
\hline S. seticornis & & & & & & & & & 18 & 18 \\
\hline \multicolumn{11}{|l|}{ Parthenopoidea } \\
\hline P. aylthoni & & & & & & & & & 1 & 1 \\
\hline P. fraterculus & & & & & & & & 2 & & 2 \\
\hline P. pourtalesii & & & & & & & & 2 & 2 & 4 \\
\hline \multicolumn{11}{|l|}{ Portunoidea } \\
\hline A. cribrarius & 77 & 32 & 17 & 26 & 11 & & & & & 163 \\
\hline Callinectes sp. & 1 & & & & & & & & & 1 \\
\hline C. danae & 448 & 117 & 46 & 5 & & 6 & & & & 622 \\
\hline C. ornatus & 1010 & 1142 & 315 & 285 & 74 & 93 & 14 & 3 & & 2936 \\
\hline C. sapidus & 2 & & & & 1 & & & & & 3 \\
\hline C. hellerii & 2 & 1 & & & & & & & & 3 \\
\hline P. ordwayi & & & & & & 1 & & & & 1 \\
\hline P. spinicarpus & & & & 1 & & 22 & 1571 & 1640 & 6322 & 2452 \\
\hline P. spinimanus & & 3 & 1 & 50 & 85 & 184 & 49 & 22 & 9 & 403 \\
\hline \multicolumn{11}{|l|}{ Xanthoidea } \\
\hline H. paulensis & 12 & 4 & 1 & 13 & & & 3 & & 4 & 37 \\
\hline H. schmitti & 4 & & 3 & & 1 & & & & & 8 \\
\hline M. nodifrons & & & & 1 & & & & & & 1 \\
\hline$P$. reticulatus & & & & 1 & & & & & & 1 \\
\hline P. coelhoi & & & & & & & & 3 & 12 & 15 \\
\hline P. hassleri & & & & & 1 & & & 3 & 9 & 13 \\
\hline P. perlatus & & & & & & & & & 1 & 1 \\
\hline \multicolumn{11}{|l|}{ Pinnotheroidea } \\
\hline Pinnixa sp. & 2 & & & & & & & & 3 & 5 \\
\hline Total of individuals & 1619 & 1441 & 6551 & 1098 & 510 & 723 & 3781 & 1808 & 10839 & 9315 \\
\hline Total of species & 14 & 12 & 13 & 16 & 13 & 13 & 13 & 15 & 20 & 38 \\
\hline
\end{tabular}

species with positive coefficients mainly occurred at greater depths (35 and $40 \mathrm{~m}$ ), with lower temperatures and lower phi values. The species with negative coefficients occurred more often at the shallower sites, with higher temperatures and higher phi values (Table 3 \& Fig. 7).

The second pairing, $\mathrm{SP}_{2} \times \mathrm{EF}_{2}$, showed lower coefficients and was represented by 2 species with negative coefficients (Parthenope pourtalesii and Portunus spinimanus), and only one with a positive coefficient (Rochinia gracilipes) because of its phi factor.

\section{Cluster analysis}

The dendrogram of sample similarities (mode Q) showed 3 groups. Group A was formed by the outermost samples (35 and $40 \mathrm{~m}$ ); group B by samples from the intermediate zone $(20,25$ and $30 \mathrm{~m})$; and group $\mathrm{C}$ by samples from the inner zone $(2,5,10$ and $15 \mathrm{~m})$ (Fig. 8a).

The species groupings also revealed 3 groups, which were closely related to the sites of occurrence of these species. Group A was composed of 6 species, distributed mainly in the intermediate zone, with the exception of Callinectes ornatus which occurred most often at depths of 2 and $5 \mathrm{~m}$, although it was found down to $35 \mathrm{~m}$. Group B consisted of species which occur in the outermost zones and group $\mathrm{C}$ of species in the shallower areas (Fig. 8b).

\section{DISCUSSION}

According to Sumida \& Pires-Vanin (1997), the changes in the benthic fauna off Ubatuba clearly follow the depth gradient and are probably related to changes in sediment, and the physical stability of the local water masses. Pires (1992) stated that between 10 and $40 \mathrm{~m}$, sediment type is the predominant factor, and at depths over $40 \mathrm{~m}$, temperature is the principal factor governing faunal distribution. Other studies in the region conducted by Paiva (1990) and Pires-Vanin (1993) also reported 
changes in macrofaunal composition between 10 and $100 \mathrm{~m}$ depth.

The estimated diversity varied with depth and was closely related to the evenness data. In the bays, the highest diversity estimated was at the $15 \mathrm{~m}$ isobath, where the sediment contained less silt and clay than in the shallower areas. Lower estimates of diversity were obtained in the 2 to $5 \mathrm{~m}$ zone, where the swimming crab Callinectes ornatus predominated. In the outer area, the index remained practically constant, with an exception at $35 \mathrm{~m}$ where the predominance of the swimming crab Portunus spinicarpus generated the lowest diversity value and evenness of the entire area sampled. $P$. spinicarpus reached its greatest abundance at this site during summer and is a good indicator of the cold Southern Atlantic Central Water (SACW) mass. The seasonal entry of SACW causes movements of water and organisms, and a marked change in water temperature. Similarly, Pires (1992) reported that P. spinicarpus represents about $90 \%$ of the megafauna in the area influenced by the SACW and that in summer, at a depth of $50 \mathrm{~m}$, the diversity index was near zero because of the massive presence of this species.

The lower diversity values estimated for the zones shallower than $15 \mathrm{~m}$ were associated with the predominantly silt-clay sediments in these areas, whereas at depths over $20 \mathrm{~m}$ the sediment was more heterogeneous and diversity increased. Felder \& Chaney (1979), Wenner et al. (1983) and Abelló et al. (1988) showed that sites with heterogeneous sediments support a greater diversity because of the wide variety of microhabitats formed within the substrate.

Menge \& Sutherland (1976) explained that diversity gradients are linked to a dynamic interaction of predation, competition and the degree of heterogeneity (spatial and temporal) in the environment, where the predominant factors in any situation depend upon the trophic level of the group being analyzed and the total trophic complexity of the local community.

The results of the multivariate analysis indicated that the species of brachyuran crabs off Ubatuba are distributed mainly according to depth, water temperature and sediment texture. It was, therefore, possible to classify the study area into 3 zones, according to depth and the typical species at each site. The inner zone was characterized by the presence of species which mainly occur down to $15 \mathrm{~m}$. The intermediate zone (20 to $30 \mathrm{~m}$ ) harbors species with wide bathymetric distributions. The outer zone ( 35 to $40 \mathrm{~m}$ ) harbors 9 species, of which only Portunus spinicarpus, Leurocyclus tuberculosus and Leucippa pentagona may occur (in lower numbers) in the shallower zones.

In the cluster analysis, some species served as indicators of the groups, when they were more frequent and abundant in a series of samples than in others. Per-

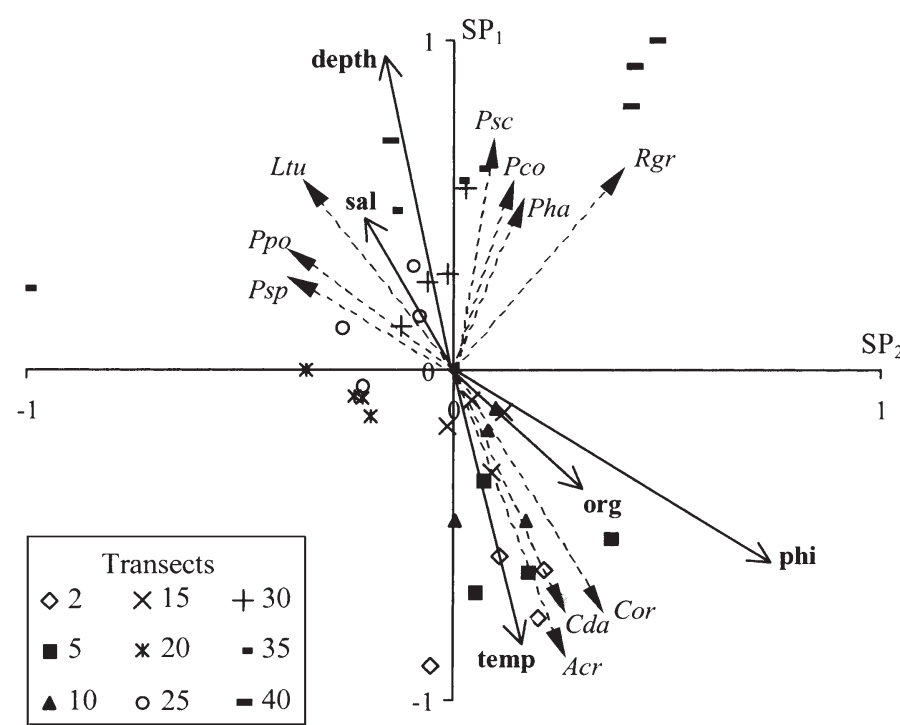

Fig. 7. Canonical variate analysis of sites, crab species, and environmental factors. (Abbreviations as in Table 3)

Table 3. Canonical analysis. Relationships between 5 environmental factors and 22 brachyuran species: correlation between the original variables and canonical variates. (Boldface $=$ species with relatively high correlation coefficients)

\begin{tabular}{|lcrr|}
\hline Species & \multirow{2}{*}{ Abbreviation } & \multicolumn{2}{c|}{ Canonical variate } \\
& & $\mathrm{SP}_{1}$ & $\mathrm{SP}_{2}$ \\
\hline P. spinicarpus & Psc & $\mathbf{0 . 6 6}$ & 0.11 \\
R. gracilipes & Rgr & $\mathbf{0 . 5 9}$ & $\mathbf{0 . 3 9}$ \\
L. tuberculosus & Ltu & $\mathbf{0 . 5 7}$ & -0.36 \\
P. coelhoi & Pco & $\mathbf{0 . 5 5}$ & 0.15 \\
P. hassleri & Pha & $\mathbf{0 . 5 3}$ & 0.15 \\
L. spinosa & Lsp & 0.43 & -0.37 \\
L. pentagona & Lpe & 0.39 & -0.04 \\
C. antillensis & Can & 0.38 & -0.03 \\
S. seticornis & Sse & 0.36 & 0.02 \\
P. tuberculata & Ptu & 0.34 & -0.07 \\
P. portalesii & Ppo & 0.33 & $-\mathbf{0 . 3 9}$ \\
P. spinimanus & Psp & 0.30 & $-\mathbf{0 . 3 8}$ \\
P. mediterranea & Pme & 0.009 & -0.15 \\
A. cribrarius & Acr & $-\mathbf{0 . 8 4}$ & 0.29 \\
C. ornatus & Cor & $\mathbf{- 0 . 7 4}$ & 0.30 \\
C. danae & Cda & $\mathbf{- 0 . 7 0}$ & 0.25 \\
H. schmitti & Hsc & -0.42 & 0.05 \\
P. punctata & Ppu & -0.37 & 0.22 \\
L. ferreirae & Lfe & -0.20 & 0.26 \\
H. paulensis & Hpa & -0.10 & 0.20 \\
H. pudibundus & Hpu & -0.09 & 0.21 \\
M. bicornutus & Mbi & -0.08 & -0.13 \\
Environmental factors & & & \\
\hline Depth & & EF & EF \\
Salinity & sal & $\mathbf{0 . 9 6}$ & -0.16 \\
Bottom temperature & temp & 0.43 & -0.23 \\
Phi & & $\mathbf{- 0 . 7 7}$ & 0.18 \\
Organic matter & org & $\mathbf{- 0 . 6 0}$ & $\mathbf{0 . 7 3}$ \\
Variance extracted & & -0.36 & 0.31 \\
Canonical correlation coefficients & 0.48 & 0.39 \\
& & 0.99 & 0.98 \\
\hline
\end{tabular}



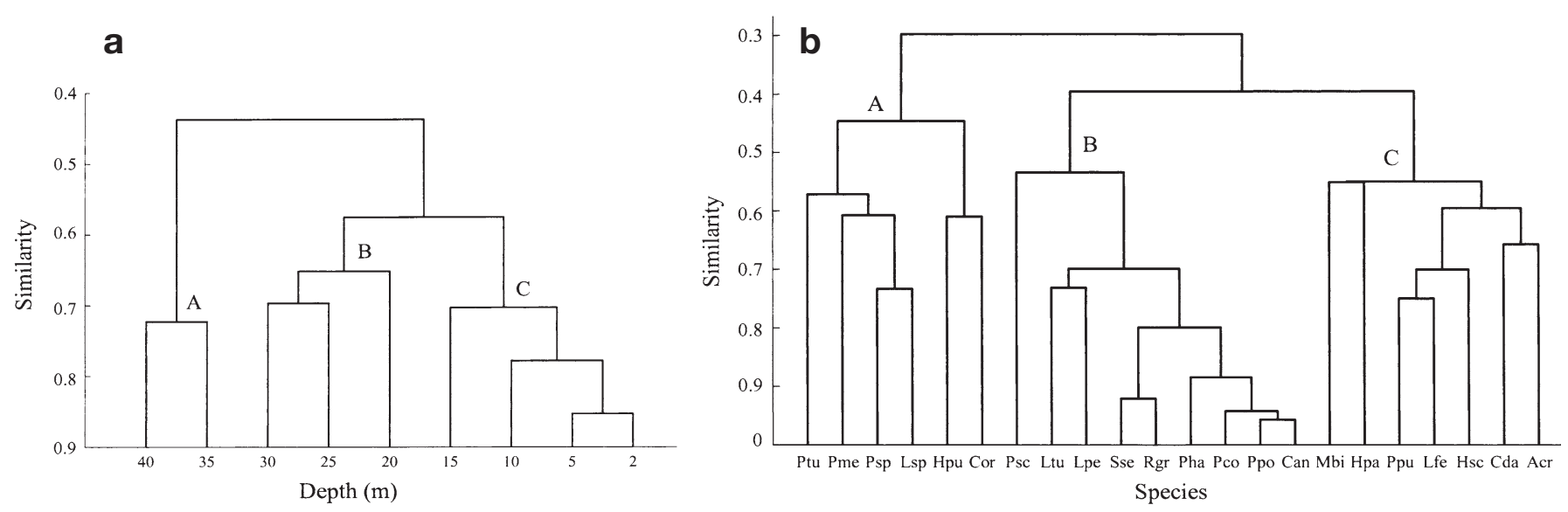

Fig. 8. Groups of (a) sample units and (b) species formed by cluster analysis (UPGMA, Canberra) (Abbreviations as in Table 3)

fect indicators would be when the species are present only in one group and do not appear in others (Field 1971). The swimming crabs Callinectes danae and Arenaeus cribrarius were indicator-species of the 2 to $15 \mathrm{~m}$ group, as they were more abundant and were associated with shallower depths, higher temperatures and finer sediments. Studies of the distribution of $A$. cribrarius by Pinheiro et al. (1996) and C. danae by Chacur \& Negreiros-Fransozo (2001) also demonstrated that these environmental factors are associated with the greater abundance of this species.

In the intermediate zone, no indicator species was identified because all the species found here also occured in adjacent zones. One example is Callinectes ornatus: although $73 \%$ of the individuals were collected between 2 and $5 \mathrm{~m}$, its distribution extended down to $35 \mathrm{~m}$. This area apparently represents a transition between the bay interior and the open sea.

On the other hand, of the 9 brachyurans which formed the group characterizing the 35 to $40 \mathrm{~m}$ zone, 6 (Stenorhynchus seticornis, Rochinia gracilipes, Pilumnoides coelhoi, Pilumnoides hassleri, Parthenope pourtalesii and Cryptodromiopsis antillensis) can be considered perfect indicators because they occurred only at these depths. Portunus spinicarpus, Leurocyclus tuberculosus and Leucippa pentagona were also good indicators, as demonstrated by canonical correlation analysis in which they were associated with greater depth, lower temperatures and coarser sand. Little is known about the biology of these species; however, Pires (1992) reported that $P$. spinicarpus and $L$. tuberculosus are common in sandy bottoms and cold waters at depths around $50 \mathrm{~m}$ on the continental shelf off Ubatuba. Her findings accord with our data, although we found that the 2 species appeared somewhat deeper.

We found that the 2 species Callinectes ornatus and Hepatus pudibundus were dominant in the inner zone. Previous studies by Fransozo et al. (1992) and
Negreiros-Fransozo \& Nakagaki (1998) of brachyurans in the bays of the Ubatuba region also found that these species are dominant. The scarcity of $H$. pudibundus at the $35 \mathrm{~m}$ isobath is probably influenced by the locally coarse sediment, which is difficult for the crab to burrow in. Previous reports by Negreiros-Fransozo et al. (1999a,b) and Mantelatto \& Fransozo (2000) showed that $C$. danae is the second-most dominant species in this environment. The difference in order of abundance may result from the design of their studies, in which the collection points were located near river mouths where C. danae occurs in high densities.

In the outer zone, Portunus spinicarpus dominated. Although it is present in large numbers only in summer, $P$. spinicarpus plays an important role in the dynamics of the benthic community. Pires (1992) stated that this portunid is one of the most important species in the Ubatuba shelf community and is especially abundant in the frontal zone of the SACW.

Even though the area examined in our study did not cover a wide depth range, as did the studies of Pires (1992) and Sumida \& Pires-Vanin (1997), it was still possible to note changes in the composition and abundance of species that followed the depth gradient. Portunus spinicarpus was extremely important in the community on bottoms deeper than $35 \mathrm{~m}$ and Callinectes ornatus dominated in the inner zone.

Acknowledgements. FAPESP (Fundação de Amparo à Pesquisa do Estado de São Paulo) awarded a doctoral scholarship (\# 97/12106-3) to G.B. and financially supported the collections (\# 94/4878-8; 97/12108-6; 97/12107-0; 98/3134-6). We extend our thanks to the many colleagues from the NEBECC group who helped us with sampling and laboratory analysis; to M. L. Negreiros-Fransozo and J. Reid for their constructive comments on the manuscript and great help with the English language; and to L. Trinca for statistical support. All sampling in this study was conducted in compliance with the applicable state and federal laws. 


\section{LITERATURE CITED}

Abelló PF, Valladares J, Castellón A (1988) Analysis of the structure of decapod crustacean assemblages off the Catalan coast (North-west Mediterranean). Mar Biol 98:39-49

Aschan M (1990) Changes in soft bottom macrofauna communities along environmental gradients. Ann Zool Fenn 27: 329-336

Blake JA, Grassle JF (1994) Benthic community structure on the U.S. South Atlantic slope off the Carolinas: spatial heterogeneity in a current-dominated system. Deep-Sea Res Part II 41:835-874

Borg JA, Schembri PJ (1999) Bathymetric distribution of decapods associated with a Posidonia oceanica meadow in Malta (Central Mediterranean). In: Klein JCVV, Schram FR (eds) The biodiversity crisis and crustacea. Crustacean Issues Vol. 12, AA Balkema, Rotterdam, p 119-130

Chacur MM, Negreiros-Fransozo ML (2001) Spatial and seasonal distributions of Callinectes danae (Decapoda, Portunidae) in Ubatuba Bay, São Paulo, Brazil. J Crustacean Biol 21:414-425

Felder DL, Chaney AH (1979) Decapod crustacean fauna of Seven and One-half Fathom Reef, Texas: species composition, abundance, and species diversity. Mar Sci 22:1-29

Field JG (1971) A numerical analyses of changes in the softbottom fauna along a transect across False Bay, South Africa. J Exp Mar Biol Ecol 7:215-253

Fransozo A, Negreiros-Fransozo ML, Mantelatto FLM, Pinheiro MAA, Santos S (1992) Composição e distribuição dos Brachyura (Crustacea, Decapoda) do sublitoral não consolidado na Enseada da Fortaleza, Ubatuba (SP). Rev Bras Biol 52:667-675

Gauch HG, Whittaker RH (1981) Hierarchical classifications of community data. J Ecol 69:537-557

Gittins R (1985) Canonical analysis: A review with applications in ecology. Springer-Verlag, Berlin

Hakanson L, Jansson M (1983) Principles of lake sedimentology. Springer-Verlag, Berlin

Hecker B (1990) Variation in megafaunal assemblages on the continental margin south of New England. Deep-Sea Res 37:37-57

Hyland J, Baptiste E, Campbell J, Kennedy J, Kropp R, Williams S (1991) Macroinfaunal communities of the Santa Maria Basin on the continental shelf and slope. Mar Ecol Prog Ser 78:147-161

Krebs CJ (1998) Ecological methodology, 2nd edn. Benjamin/ Cummings, Menlo Park, CA

Lance GM, Williams WT (1967) A general theory of classificatory sorting strategies. I. Hierarchical systems. Comput J 9:373-380

Mantelatto FLM, Fransozo A (2000) Brachyuran community in Ubatuba Bay, northern coast of São Paulo State, Brazil. J Shellfish Res 19(2):701-709

Martin JW, Davis GE (2001) An updated classification of the Recent Crustacea. Science Series 39. Natural History Museum of Los Angeles County, Los Angeles

Melo GAS (1996) Manual de identificação dos Brachyura (caranguejos e siris) do litoral brasileiro. Plêiade/FAPESP Ed., São Paulo

Editorial responsibility: Otto Kinne (Editor),

Oldendorf/Luhe, Germany
Menge BA, Sutherland JP (1976) Species diversity gradients: synthesis of the roles of predation, competition, and environmental stability. Am Nat 110:351-369

Negreiros-Fransozo ML, Nakagaki JM (1998) Differential benthic occupation by crabs in the Ubatuba Bay, São Paulo, Brazil. J Shellfish Res 17(1):293-297

Negreiros-Fransozo ML, Nakagaki JM, Reigada ALD (1999a) Seasonal occurrence of decapods in shallow waters of a subtropical area. In: Klein JCVV, Schram FR (eds) The biodiversity crisis and crustacea, Crustacean Issues Vol. 12, AA Balkema, Rotterdam, p 351-361

Negreiros-Fransozo ML, Reigada ALD, Nakagaki JM (1999b) Diel variations in decapod catch rate and size of captured individuals in a subtropical area of Brazil. In: Klein JCVV, Schram FR (eds) The biodiversity crisis and crustacea, Crustacean Issues Vol. 12, AA Balkema, Rotterdam, p 643-656

Paiva PC (1990) Padrões de distribuição e estrutura trófica dos anelídeos poliquetas da plataforma continental do litoral norte do Estado de São Paulo. Universidade de São Paulo, Instituto Oceanográfico, São Paulo. MSc thesis

Pielou EC (1966) The measurement of diversity in different types of biological collections. J Theor Biol 13:131-144

Pielou EC (1975) Ecological diversity. Wiley-Interscience, New York

Pinheiro MAA, Fransozo A, Negreiros-Fransozo ML (1996) Distribution patterns of Arenaeus cribrarius (Lamarck, 1818) (Crustacea, Portunidae) in Fortaleza Bay, Ubatuba (SP), Brazil. Rev Bras Biol 56:705-716

Pires AMS (1992) Structure and dynamics of benthic megafauna on the continental shelf offshore of Ubatuba, southeastern Brazil. Mar Ecol Prog Ser 86:63-76

Pires-Vanin AMS (1993) A macrofauna bêntica da plataforma continental ao largo de Ubatuba, São Paulo, Brasil. Publ Esp Inst Oceanogr 10:137-158

Rex MA (1981) Community structure in the deep-sea benthos. Ann Rev Ecol Syst 12:331-353

SAS Institute (1996) SAS/STAT Software, Release 6.12. SAS Institute, Cary, NC

Schaff T, Levin L, Blair N, Demaster D, Pope R, Boehme S (1992) Spatial heterogeneity of benthos on the Carolina continental slope: Large (100 km)-scale variation. Mar Ecol Prog Ser 88:143-160

Soto LA, Manickhand-Heileman S, Flores E, Licea S (1999) Processes that promote decapod diversity and abundance on the upper continental slope of the southwestern Gulf of Mexico. In: Klein JCVV, Schram FR (eds) The biodiversity crisis and crustacea, Crustacean Issues Vol. 12, AA Balkema, Rotterdam, p 385-400

Sumida PYG, Pires-Vanin AMS (1997) Benthic associations of the shelfbreak and upper slope off Ubatuba-SP, southeastern Brazil. Estuar Coast Shelf Sci 44:779-784

Tucker M (1988) Techniques in Sedimentology. Blackwell Scientific Publications. Cambridge.

Wenner EL, Knott DM, Van Dolah RF, Burrel Jr VG (1983) Invertebrate communities associated with hard bottom habitats in the South Atlantic Bight. Estuar Coast Shelf Sci $17: 143-158$

Submitted: April 7, 2003; Accepted: May 5, 2004

Proofs received from author(s): September 17, 2004 